\title{
Citing Case LaW: A Comparative Study Of Legal TeXtbooks on EUROPEAN HUMAN RIGHTS LAW
}

\author{
Amalie Frese ${ }^{*}$ and Henrik Palmer Olsen ${ }^{\dagger+}$
}

Recent years have seen increased interest in data-driven methods in legal research. Technologies provide new automated alternatives to traditional doctrinal approaches, which rely on manual information retrieval. In this article, we address one aspect of this development. On the basis of a citation network containing judgments on Article I4 of the European Convention of Human Rights, we identify which cases are most frequently cited and explicitly used in the legal argumentation of the European Court of Human Rights. We subsequently compare our findings with presentations of Article I4 in German, French and British textbooks. We aim to demonstrate that I) network analysis can provide relevant input to legal analysis by relying on objective measures of case importance and 2) scholarship relying on traditional doctrinal methods is more dependent on the authors' subjective outlook than necessary.

Keywords: network analysis, case citations, doctrinal legal analysis, textbooks, legal methodologies, human rights law, Article I4 ECHR

\section{TABLE OF CONTENTS}

I. INTRODUCTION: THE LEGAL METHOD VERSUS NETWORK ANALYSIS ......... 92

II. NETWORK ANALYSIS AS A LEGAL RESEARCH TOOL ......................................96

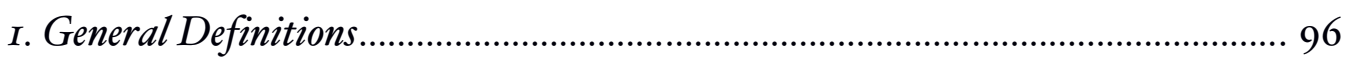

2. Specific Demarcations and Possible Sources of Error ............................................98

* Internationalisation Postdoc, Faculty of Law, University of Vienna and affiliated researcher at Centre of Excellence for International Courts (iCourts) the Faculty of Law, University of Copenhagen, Copenhagen.

$\dagger$ Professor at Centre of Excellence for International Courts (iCourts) and Vice-Dean of the Faculty of Law, University of Copenhagen, Copenhagen.

$\ddagger$ We thank Ionannis Panagis, Davide Morisi, Magnus Esmark and Jorge Cardoso Leitão whose expertise greatly assisted the data analysis. An early version of the manuscript was presented at a meeting of the Network of Legal Empirical Scholars (NoLesLaw) at the University of Umeå in March 20I7 and we would like to thank the participants for comments and suggestions. Finally, we thank two anonymous reviewers for comments that helped improve the manuscript. 
III. THE ARTICLE I4 NETWORK AND ITS VISUALISATION IOI

IV. COMPARISON OF NETWORK AND TEXTBOOK ACCOUNTS OF ARTICLE I4 ECHR IO3

I. Textbook References to Case Law and Their In-degree Ratings ......................... $\mathrm{IO} 3$

2. Textbook References with a Very Low In-degree Rating ................................... 105

3. Omission of fudgments with a High In-degree Rating....................................... 108

4. Interim Conclusion on In-degree Ratings ........................................................... II 2

V. COMPARING LEGAL EXPERTISE ................................................................. II 3

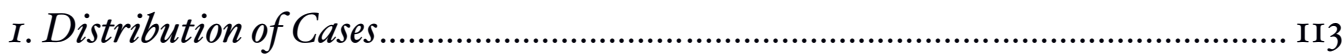

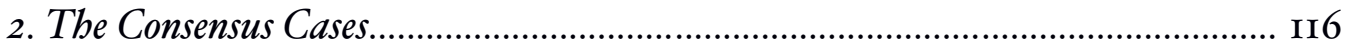

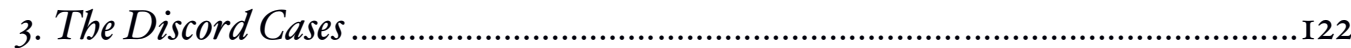

4. Interim Conclusions of Comparison of Textbook Analyses and Network ........... I29

VI. CONCLUSIONS: THE BENEFIT OF USING NETwORK ANALYSIS IN LEGAL RESEARCH.

\section{INTRODUCTION: THE LEGAL METHOD VERSUS NETWORK ANALYSIS}

What is valid law? The aim of legal doctrinal scholarship is to answer this question within some defined area of the law, at a defined point in time and in a defined jurisdiction. Identifying and interpreting relevant sources of law is what determines the content of valid law in doctrinal scholarship. Case law is generally one such recognised source of law, which must be taken into account where it is relevant. The role and use of case law vary both across jurisdictions and across fields of law, but generally case law represents the use of law in practice and therefore cannot be ignored. However, which methodological considerations justify the inclusion (or exclusion) of one judgment (or set of judgments) rather than another in a doctrinal account of law?

In this article, we discuss this question in the context of European human rights law, with a focus on the identification of which judgments of the European Court of Human Rights (ECtHR) should be included in doctrinal accounts of this field of law. ${ }^{\mathrm{I}}$ While it is commonly accepted that European

I In this article, we do not use the term 'precedent' because this is a highly theorised concept associated in quite a specific way with a status conferred upon certain 
human rights law can only be properly and accurately understood by relying on the case law of the ECtHR, in most cases it remains unclear how the judgments that are included in accounts of this law are selected from the very large pool of case law available.

We aim to compare the use of case law citation in traditional doctrinal accounts of European human rights law to a case law citation network approach to law. ${ }^{2}$ We illustrate what we consider shortcomings of the traditional doctrinal approach in comparison to a network-informed approach to law, in particular regarding the selection of cases that characterise and shape a specific area of that law.

Our data for this comparison are chapters in three different textbooks. These three chapters all seek to set out what the law is under Article I4 (prohibition of discrimination) of the European Convention of Human Rights (ECHR/the Convention). The textbooks are written in three different languages and published in three different countries, but all aim to present

judgments. Instead, we rely on the ECtHR's citation practice to identify explicit citations of its own case law when issuing new judgments.

2 Network analysis is a relatively new method in legal science, but there is already research in the area. In the Nordic countries, there are two research groups using this method. At Umeå University, Mattias Derlen and Johan Lindholm have for several years been using network analysis and similar methods to conduct research on EU law; see their most recent article Mattias Derlen and Johan Lindholm 'Characteristics of Precedent: The Case Law of the European Court of Justice in Three Dimensions' (2015) 16(5) German Law Journal I073. In Denmark, related research has been carried out at the Danish National Research Foundation's Centre of Excellence for International Courts (iCourts) at the University of Copenhagen. See for example Urška Šadl and Michael Rask Madsen, 'Did the Financial Crisis Change European Citizenship Law? - An Analysis of Citizenship Rights Adjudication Before and After the Financial Crisis' 201622 European Law Journal. The approach used in the present article is therefore mainly introductory and so does not use the very latest technologies. For an overview of the various research approaches in the area, see Urska Sadl \& Henrik Palmer Olsen, 'Empirical Studies of the Webs of International Case Law - A New Research Agenda' 20158 iCourts Working Paper <http://papers.ssrn.com/sol3/papers.cfm?abstract_id=2671678> accessed 9 August 2018. 
the law of the ECHR as of 2OI $4 \cdot^{3}$ The textbooks are Droit Européen Des Droits De L'bomme 4 by Jean-Francois Renucci (the French textbook), Europäische Menschenrechtskonvention ${ }^{5}$ by Christoph Grabenwarter and Katharina Pabel (the German textbook) and Jacobs, White and Ovey's The European Convention on Human Rights (the UK textbook). ${ }^{6}$ To our knowledge, they are widely used in university courses on European human rights in France, Austria and Germany, and the UK respectively.

We first identified all the textbooks' references to case law from the ECHR in their chapters on Article I4 ECHR and built three separate lists of cases. Then we built a citation-network consisting of all citations between all cases concerning Article I4 ECHR. We retrieved this information from ECtHR's own database, HUDOC, and fed it into software that could order and visualise the information, thus creating a network where cases receiving citations are 'nodes' and citations among them are 'ties'. We thus create an empirical basis for claims about which cases the ECtHR itself cites more often than others.

Our study proceeds in two steps. After introducing how network analysis can function as a tool for legal analysis and introducing the main characteristics of the Article I4 network in sections II and III respectively, we move on in section IV to compare the network's citations to the textbook chapters' references to case law. We look at which cases figure in both the network and textbooks and which cases only figure in one or none of the datasets. In section $\mathrm{V}$, we then compare the references to case law in each of the textbook chapters both to the other textbooks as well as to the network.

3 The three textbooks are from respectively 2014, 2015 and 2016. It was not possible to obtain three textbooks from different jurisdictions from exactly the same year of publication. While this could pose a problem to the comparability of the three textbooks, none of the three are referring to case law after 20I4, therefore this is not in practice a problem for our analysis.

4 Jean-Francois Renucci, Droit Européen Des Droits De L'bomme (6th edn, LGDJ 2015).

5 Christoph Grabenwarter and Katharina Pabel, Europäische Menschenrechtskonvention (6th edn, C.H.BECK 2OI6).

6 Bernadette Rainey, Elizabeth Wicks and Clare Ovey, The European Convention on Human Rights, (6th edn, Oxford University Press 20I4). 
Our study is guided by two hypotheses. One hypothesis is that when comparing traditional doctrinal accounts of European human rights law to a systematic network analysis of the case law, there will be significant discrepancies between the cases cited by the textbooks as illustrating the law and the cases that are actually cited by the ECtHR in support of their judgments. We attribute this discrepancy to the two different methods for identifying what is considered to be relevant practice. The citation network relies on the ECtHR's actual citation practice, whereas textbooks rely on the outlook and experience of the authors. Our second hypothesis is that when the textbook references are compared with each other, we can detect that the textbook authors' outlook and perception of case importance differ.

With this article, we also wish to demonstrate that where the law in a given field is determined to a large extent through case law, and where there is a lot of case law, a network analysis of case-to-case citations makes it possible to conduct doctrinal research in new ways. The use of this method means that it is not the researcher's subjective assessment, but the actual citation practice of a court that guides the selection of the judgments used to illustrate a legal problem. This creates a broader empirical basis for an analysis and account of the relevant law. ${ }^{7}$ This new approach can have methodological implications for legal research more generally and constitute a progressive new approach to legal analysis which can be merged with and enrich traditional legal analysis.

We have chosen to focus on European human rights law because this area of law is particularly characterised by the on-going development of case law. The Convention dates back to I950 and, with the exception of the addition of 16 protocols, no significant amendments have been made to the Convention since it was first agreed. On the other hand, there has been a very significant development of case law related to the Convention. The key to

7 It should also be recognised that it is a separate issue to identify the underlying reasons why a court chooses to refer to an earlier judgment as a justification for its decision. To examine this in more detail would require a separate research project and we will not pursue this further in the current article. This article is based on the assumption that the ECtHR's citations of previous judgments are the general method by which it summarises the existing law in order to apply it to the case before it. This is of course also a way of justifying the decision reached in the case. 
understanding current European human rights law is not the text of the Convention but the case law. This, then, is the reason why we have chosen European human rights law to illustrate how network analysis can be used as a legal research tool.

Furthermore, we limited the network by selecting only the judgments in which Article I4 of the Convention is referred to. The Article I4 network contains 636 judgments from the establishment of the ECtHR up to and including 2OI4. Article ${ }_{4}$ ECHR prohibits discrimination. More precisely, it provides that the enjoyment of rights and freedoms in the Convention must be secured 'without discrimination on any grounds such as any ground such as sex, race, colour, language, religion, political or other opinion, national or social origin, association with a national minority, property, birth or other status'. ${ }^{8}$ We chose Article I4 for practical reasons, rather than substantive legal reasons. There are enough cases (636), though it is not an area that gives rise to the biggest caseload at the ECtHR. 636 cases is a sufficient number for the purpose of building a network, with enough to clearly show some cases as being central and others as peripheral, which serves to illustrate our points about the advantages of using network analysis for legal analyses.

\section{NETWORK ANALYSIS AS A LEGAL RESEARCH TOOL}

\section{General Definitions}

Simply put, network analysis consists of a mapping and analysis of relations between nodes (for example individuals or as here judgments). In the present context, these elements are judgments delivered by the ECtHR and the relations between them created by the ECtHR's own citations of previous judgments. When a judgment cites a previous judgement, a relationship is created between the two judgments.

Network analysis thus facilitates analysis of large quantities of case law. However, the applicability of the method depends on one's ability to identify case-to-case citations. Since the ECtHR explicitly and frequently cites its own previous decisions and judgments, it seems uncontroversial to assume

8 European Convention of Human Rights, Article I4 <https://www.echr.coe.int/ Documents/Convention_ENG.pdf>. 
that it thereby indicates that it regards these earlier decisions and judgments as relevant sources of law. ${ }^{9}$ Citation-impact can therefore be associated with meaningful legal impact. ${ }^{\text {IO }}$ If the ECtHR cites a previous case as part of its reasoning in a subsequent case, then we assume that the cited case has relevance for the new decision. We call this phenomenon citation-impact.

Cases which are never cited have zero citation-impact. Cases which are frequently cited have high citation-impact. If one assumes that the ECtHR does not cite cases randomly, but rather consciously makes use of meaningful citations, then citation impact can be seen as a proxy for legal impact. That said, it is important to note that it is no more than a proxy. Cases might be cited many times simply because there are many cases dealing with the same, perhaps trivial, problem. Other cases may be legally more important, but cited much less, for instance if the problem dealt with does not occur frequently in other cases. One should not confuse a quantitative measure (number of citations) with a qualitative measure (legal impact), but the quantitative measure may nonetheless be used to guide the search for the qualitatively important cases, especially if one recognizes that it is the active use by the ECtHR of its own previous case law that determines the measure

9 A citation network naturally only reveals how often a given judgment has been cited and which judgments have cited it. The number of citations cannot in itself say anything about how judgments have affected the development of the law to a particular degree, but it is natural to start from the assumption that a judgment that has been frequently cited will have had some level of influence.

Io It should be noted that there exists another measure of importance, namely network centrality. This measure not only includes the number of times a case is cited, but also the 'in-degree' of cases that case cites, as well as the 'in-degree' of the cases that cite it. Case centrality then measures importance by showing how strong a case is in operating as an information hub. Centrality in this sense is a matter of how many connections between cases pass through a given node (case). There are many different mathematical models for measuring case centrality. See for example $<$ https://en.wikipedia.org/wiki/HITS_algorithm> for an introduction. In our experience, while case centrality measures differ to some extent from in-degree measures, the most cited cases are generally also the most central cases. Since we wanted to make our point using a simple measure, we rely solely on in-degree in this article. 
of legal impact. ${ }^{\text {II }}$ Our proposition therefore is that citation analysis should be used in combination with a more qualitative approach, which identifies the most prevalent conceptual distinctions in the case law and presents them in a systematic manner. Hence, we do not argue that citation network analysis should replace traditional doctrinal approaches, but instead that citation network analysis should be used to empirically support and thereby enrich the traditional approach.

In the following sections, we use the metric 'in-degree rating' as a proxy for measuring case importance in the Article I4 network. In-degree measures how many times a reference is made to a particular judgment. The higher the in-degree number, the more important the case is assumed to be for the ECtHR's practice. For example, if a judgment has an in-degree rating of Io, this means that it has been referred to in Io subsequent judgments and must accordingly be considered more important than a case that is only cited once and has in-degree rating $\mathrm{I}^{\mathrm{I}}{ }^{2}$

\section{Specific Demarcations and Possible Sources of Error}

As stated, the judgments in the network have been identified and selected by using the ECtHR's own search engine, HUDOC; the network only contains citations of judgments in the more restricted 'Article I4 network'. A number of issues should be mentioned in this regard.

First, not all the judgments in this network are necessarily decided on the basis of Article I4 of the Convention, even if the judgment mentions Article I4 at some point. This means that some cases included in the network have been decided primarily on the basis of another article and the ECtHR has thereafter ruled that it has not been necessary to decide whether the case involved an independent breach of Article I4. For example, while the case of

II It should further be noted that there can be various reasons why the judgment has been cited. For example, an earlier judgment may be cited because the ECtHR wishes to distance its newer judgment from the earlier one, i.e. to cite, not as a way of founding the decision on arguments derived from previous cases, but to clarify that the new judgment marks a departure from or adds a new dimension to the previous case law. There is, however, a clear tendency for the cases cited in the network to be used to provide normative support for the decisions in the newer judgments.

${ }^{12}$ See footnote II above. 
Ireland $v$. $U K\left({ }_{1978}\right)^{13}$ has the highest in-degree rating in the Article I4 network, this judgment is mostly referred to for its Article 5 content. The judgment deals briefly with the alleged discrimination between two categories of terrorists (nationalists vs. Unionists in relation to Article I 4 read in conjunction with Article 5) and did not find a violation of Article I4. Clearly many references to Ireland $v$. UK are therefore not related to Article I4. This illustrates a more general challenge for network approaches to case law analysis: at the quantitative level, we cannot see exactly what the citations, constituting the ties in the network, consist of and whether the citations are relevant to Article I4. At present, quantitative network analysis must therefore be supplemented with content analysis of all ties in the network. Network analysis so far lacks the necessary code for automated analysis, although initial attempts have been made. ${ }^{\mathrm{I}}$

Nonetheless, we believe that our results are sufficiently robust for the purposes of this article. We have two reasons for this. First, the Article I4 network only includes citations between judgments in the Article I4 network. When we calculate the 'in-degree rating' of the judgments in the network, we rely solely on the citations that a given judgment receives from other judgments that are also in the network. This means that we do not include any citations a judgment may receive from judgments that are outside the Article I4 network. Consequently, Article I4 will always have been mentioned both in the citing and in the cited judgment. This does not mean that citations between cases are necessarily relevant to Article I4, ${ }^{15}$ but it does

${ }^{13}$ Ireland v UK App no 5310/7I (ECtHR, I3 December 1977).

${ }^{14}$ See for example Martin Lolle Christensen, Henrik Palmer Olsen and Fabien Tarrisan, 'Identification of Case Content with Quantitative Network Analysis: An Example from the ECtHR' in Floris Bex and Serena Villata (eds), Legal Knowledge and Information Systems (IOS Press 20I6); and Amalie Frese, 'Judicial Incrementalism: Dynamics of decision-making and jurisprudence in the domain of discrimination law at the European Court of Human Rights and the Court of Justice of the European Union' (Ph.D. thesis, Faculty of law, University of Copenhagen, 2016).

${ }^{15}$ One systematic error in the automated network analysis should be mentioned here: If case A cites both Article I 4 and, say Article 3, then case A is recorded in HUDOC as containing these two articles. The same may be true of another case, $B$. If case $B$ cites case A, this citation may be related to some issue related to Article 3 and not to Article I4. Article I4 may not be dealt with in any substantial way in either A or B. The Article I4 network will still contain both A and B and will also show a citation 
significantly enhance the chances that they are. Secondly, whenever we discuss our findings in regard to specific cases, we read these cases to qualitatively validate our findings (this is explained in greater detail below).

Another issue we want to flag is the changes that may occur in a case-to-case network over time. The network analyses we have carried out for the purposes of this article are based upon reading the whole network from the period from the establishment of the ECtHR up to and including 2014 at a single point in time. This means we look at the total calculated citations over the entire period. However, it is in principle possible to look at the citations on a year-by-year or decade-by-decade basis. This could show important and potentially useful nuances in citation patterns. As an example, we have found that the case of $A b d u l a z i z^{16}$ from 1985 is still being actively cited by the ECtHR. Conversely, Incal ${ }^{17}$ appears as a leading case in the network because it has a high in-degree number, but in fact it has not been cited since 2007 (in cases included in the network). We acknowledge this potential error, but do not find that it significantly challenges our main point.

A third issue, also related to temporal change, is the following: what if the ECtHR has changed direction in its most recent judgments? It can be said that, in so far as network analysis is based on statistical results collected from past decisions, a new individual judgment that changes the case law will not be captured by this method. While we recognise this, we also think that from a scholarly point of view, it could be argued that there will always be some uncertainty associated with the issue of whether a new judgment will have a permanent effect on the ECtHR's practice. Hence, it is only when the ECtHR starts to actually cite the case that there will be sufficient certainty that the case actually has citation impact and thereby a proven legal impact beyond the individual decision itself. ${ }^{18}$

from $B$ to $A$. If $A$ has a large in-degree, it will look like A is a very important case for Article I4, yet the large in-degree number may derive from citations mostly relating to Article 3 issues. We check for this error by manually reading the highest in-degree cases dealt with.

${ }^{16}$ Abdulaziz, Cabales, and Balkandaliv UK App no 92I4/80 (ECtHR, 28 May 1985).

${ }^{17}$ Incal v Turkey App no 22678/93 (ECtHR, 9July 1998).

I8 A further issue should be mentioned: it could be argued that the judgments of the Grand Chamber are a superior source of law compared to the judgments of the 
Overall, we conclude that we have taken sufficient steps to ensure that our data are sufficiently reliable to support the point we wish to make, namely that network analysis can be used to enhance the quality of legal analysis, as compared to traditional textbook approaches.

\section{THE ARTICLE I4 NETWORK AND ITS VISUALISATION}

The complete network contains ${ }_{3} 6 \mathrm{ECtHR}$ judgments relating to Article I4 from 23 July 1968 (Belgian Linguistics case ${ }^{\mathrm{I}}$ ) to I6 December 2014 (Chbibi Loudoudi and Others v. Belgium ${ }^{2 \circ}$ ).

The visualisation in figure I (below) shows the entire Article I4 network and creates a new and unique way to examine the law of non-discrimination. The network is meant to provide an overview of the Article I4 network. The bigger nodes indicate highly cited cases. ${ }^{2 \mathrm{I}}$

ECtHR's ordinary chambers. To clarify this, we assessed whether the judgments that have the highest in-degree ratings are judgments of the Grand Chamber. We did not find any correlation between Grand Chamber cases and high in-degree ratings. For example, Willis (2002) and Smith and Grady (1999) are not Grand Chamber judgments, but nevertheless have high in-degree ratings. Thus, it is not necessary that a judgment be decided by the Grand Chamber for it to be frequently cited by the ECtHR in subsequent judgments.

I9 'Case relating to certain aspects of the laws on the use of languages in education in Belgium', App no I474/62 (ECtHR, 23July 1968).

${ }^{20}$ Chbibi Loudoudi and Others v. Belgium, App no 52265/ro (ECtHR I6 December 2014).

${ }^{21}$ This figure can be accessed in colour as an interactive network at: http://icourts.dk/networks/sigma/articler $4 /$. It is possible to navigate around the interactive network in various ways. It is also possible to zoom in and out of the network in order to look more closely at individual judgments and their connections. 


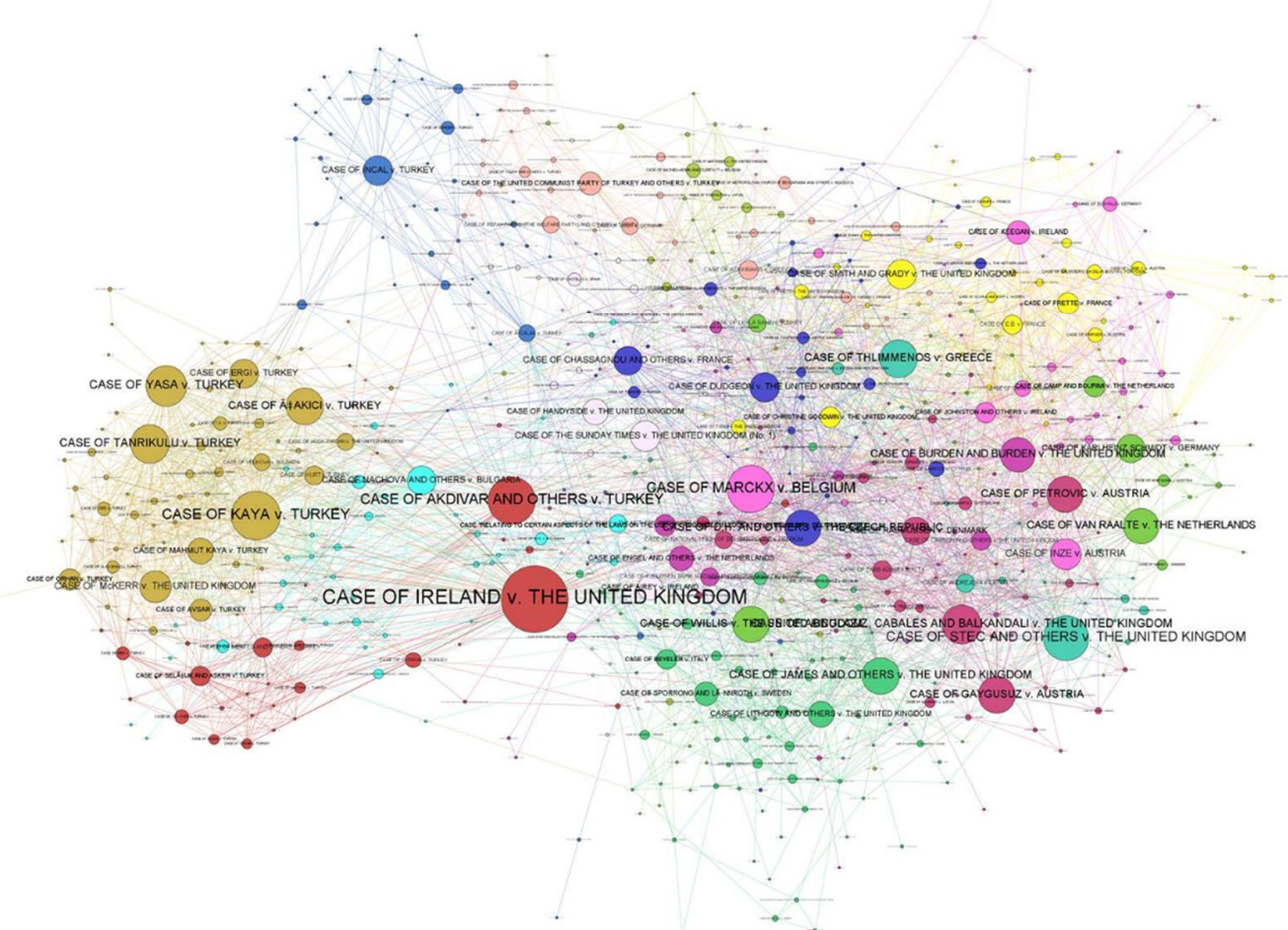

Figure I. The complete Article I4 network

The judgments in the Article I 4 network have an in-degree rating of between $\mathrm{o}$ and 86, with an average rating of 6 ingoing citations (i.e. citations a case receives from other cases) per case. Ireland $v$. $U K$ ( 1978 ) is the most frequently cited case with 86 ingoing citations.

Since one of the interests motivating our analysis is the identification of judgments with the highest citation impact, we have decided to only focus on the judgments with the highest in-degree (i.e. the highest number of citations). Inevitably, there is a certain level of discretion involved in selecting a cut-off point. We found that we could get a manageable picture of the most cited judgments in the network by focusing only on judgments with an in-degree rating over 25 . An in-degree filter of 25 leaves just $4 \mathrm{I}$ judgments $(7.2 \%)$ in the network. Figure 2 shows the $4 \mathrm{I}$ judgments in the Article I4 network with an in-degree ranking over 25 ingoing citations. 


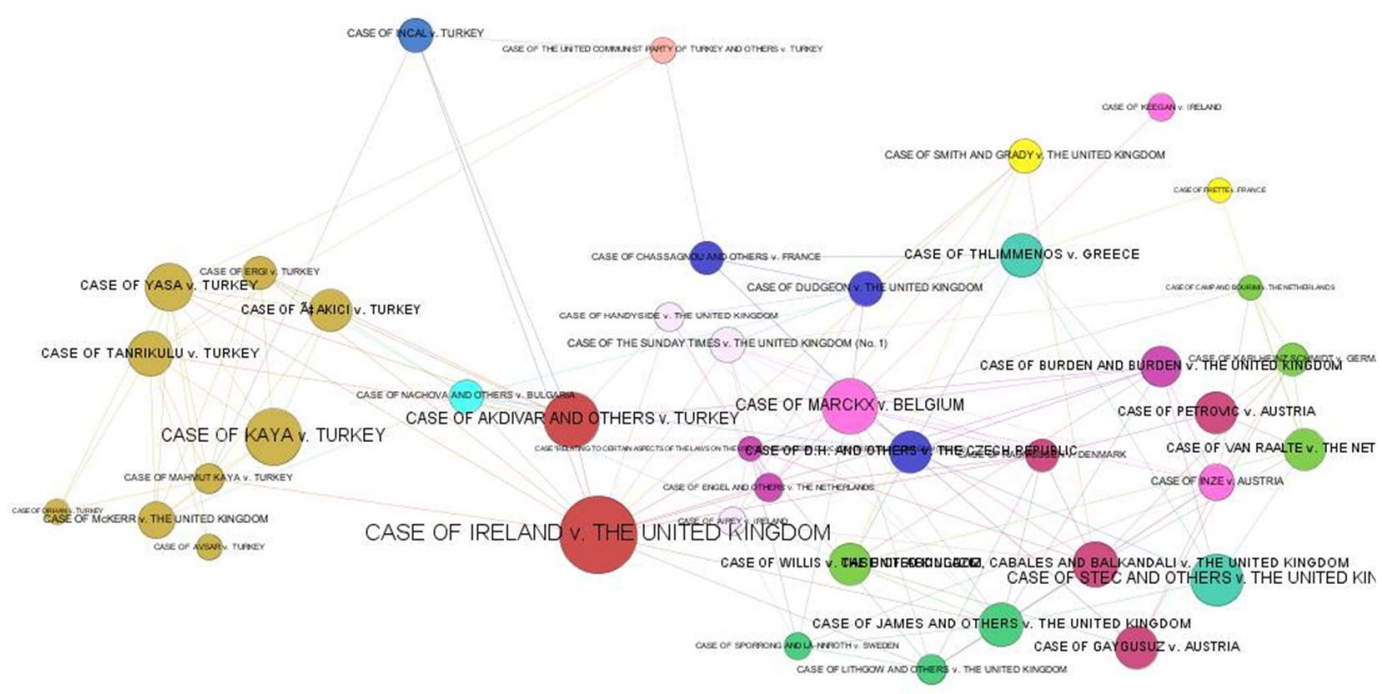

Figure 2. Fudgments in the Article I4 network with an in-degree rating of $25+.^{22}$

\section{COMPARISON OF NETWORK AND TEXTBOOK ACCOUNTS OF ARTICLE I4 ECHR}

In the following section we compare the results of the network analysis with the selected textbooks. The ambition is to assess the extent to which these accounts are based on the cases most cited by the ECtHR itself.

\section{Textbook References to Case Law and Their In-degree Ratings}

Figure 3 shows the number of references in each of the textbooks, how many of these references have a high in-degree rating when compared to the network, and the average in-degree rating of the references.

${ }^{22}$ This diagram can be accessed as a coloured interactive diagram at: http://icourts.dk/networks/sigma/articleI4/. 


\begin{tabular}{l|l|l|l} 
& $\begin{array}{l}\text { Total number } \\
\text { of references } \\
\text { to cases }\end{array}$ & $\begin{array}{l}\text { Number of } \\
\text { references to } \\
\text { cases } \\
\text { with in-degree 25+ }\end{array}$ & $\begin{array}{l}\text { Average in- } \\
\text { degree of } \\
\text { references }\end{array}$ \\
\hline Network & 636 & $4 \mathrm{I}$ & 6 \\
\hline $\begin{array}{l}\text { French Textbook } \\
\text { Droit Européen Des } \\
\text { Droits De L'bomme }\end{array}$ & 90 & 22 & $\mathrm{I3}$ \\
\hline $\begin{array}{l}\text { UK Textbook } \\
\text { The European } \\
\text { Convention } \\
\text { on Human Rights }\end{array}$ & $\mathrm{IO} 3$ & $\mathrm{I} 6$ & $\mathrm{II}$ \\
\hline $\begin{array}{l}\text { German Textbook } \\
\text { Europäische } \\
\text { Menschenrechts- } \\
\text { konvention }\end{array}$ & $\mathrm{I} 44$ & $\mathrm{I} 8$ & 8
\end{tabular}

Figure 3. Textbooks references and in-degree

As Figure 3 shows, the German textbook makes use of by far the greatest number of case references (I44), 37\% more than are found in the UK textbook. As the number of cases which the textbooks refer to with an indegree of $25^{+}$is between 16 and 22 there is a fair co-occurrence between the most cited cases in the network and the cases selected for the textbooks.

The average in-degree of cases cited in the textbooks is also higher than the average in-degree in the overall network. This is to be expected. If the average in-degree of cases cited was the same as the average in-degree in the overall network, this would suggest that cases are cited at random. In addition, $6.4 \%$ (4r/636) of the cases in the network have an in-degree of $35^{+}$. The equivalent proportion in the textbooks ranges from 12.5 to $24.4 \%$. This indicates that authors select a higher number of cases with high in-degree than if they had chosen cases as random. These numbers indicate that authors generally select cases with a higher-than-average in-degree and to a large extent also rely on 
some of the most cited cases in the network. In the following, we will explore the cases used (or not used) by the textbooks in more detail. We will compare the textbooks with each other and with the network to better describe how the textbook authors use cases. We first identify use of cases with low indegree rating (IV.2) and then we move on to identify cases with high indegree that are omitted from the textbooks (IV.3).

\section{Textbook References with a Very Low In-degree Rating}

Not only do a number of the judgments referred to by the textbooks have a very low in-degree, but some do not even appear in the Article I4 network at all. While more than $90 \%$ of the cases referred to by all three textbooks are in the network, a few cases used by the textbooks in their chapter on Article I4 do not contain any reference to that article. Figure 4 presents the proportion of cases used in the three textbooks, which fall within and outside the Article I4 network. As figure 4 below shows, between 3 and $7 \%$ of the cases used in the textbooks' chapters on Article I4 are not part of this network. 


\begin{tabular}{|c|c|c|c|}
\hline & French textbook & $\begin{array}{l}\text { German } \\
\text { textbook }\end{array}$ & UK textbook \\
\hline $\begin{array}{l}\text { Cases in } \\
\text { Article I4 } \\
\text { network }\end{array}$ & $93.4 \%$ & $96.6 \%$ & $94.2 \%$ \\
\hline $\begin{array}{l}\text { Cases not } \\
\text { in Article } \\
\text { I4 } \\
\text { network }\end{array}$ & $\begin{array}{l}6,6 \% \\
\text { 2660/03 Hajduovav. } \\
\text { Slovakia } \\
\text { 57693/Io Kalucza v. Hungary } \\
\text { 33234/07 Valiulienè v. } \\
\text { Lithuania } \\
\text { 7224/II Aghdgomelashvili and } \\
\text { Faparidze v. Georgia } \\
\text { 21986/93 Salmanv. Turkey } \\
\text { 71127/or Bevacqua and s. v. } \\
\text { Bulgaria }\end{array}$ & $\begin{array}{l}3,4 \% \\
\text { 25159/94 Hokkanen v. } \\
\text { Finland } \\
3455 / 05 \text { A and Others v. } \\
\text { The UK } \\
38590 / 10 \text { Efe v. Austria } \\
\text { 19508/o7 Granos } \\
\text { Organicos Nationales } \\
\text { SA v. Germany } \\
\text { 3681/o6 Moldovan and } \\
\text { others v. Romania (no. } \\
\text { 2) }\end{array}$ & $\begin{array}{l}\text { 5,8\% } \\
\text { I8968/o7 V.C v. } \\
\text { Slovakia } \\
\text { 13624/o3 Koky and } \\
\text { Others v. Slovakia } \\
\text { 29518/10 N.B.v. } \\
\text { Slovakia } \\
\text { 15966/o4 I.G. and } \\
\text { Others v. Slovakia } \\
\text { 61382/o9 B. v. The } \\
\text { Republic of Moldova } \\
\text { 57345/oo Budak and } \\
\text { Others v. Turkey }\end{array}$ \\
\hline Total & $100 \%$ & $100 \%$ & $100 \%$ \\
\hline$(\mathbf{N})$ & (9o) & (I44) & (IO3) \\
\hline
\end{tabular}

Figure 4. Distribution of textbook cases within and outside the Article I4 network

While the textbooks largely refer to cases which, according to the ECtHR, are relevant to Article I4, why are 3 to $7 \%$ of the cases cited not among the 636 cases which, according to the ECtHR, relate to Article I4? All three textbooks refer to cases outside the network as significant examples of the law and legal development under Article I4, either alone or as part of a series of cases, which the authors cite in support of their statements about what the law is. Reference to Aghdgomelashvili and fapadridze v. Georgia ${ }^{23}$ can be explained by the fact that it is used in the context of explaining Protocol I $2,{ }^{24}$ but we find it difficult to account for the importance of the remaining cases in the context of Article I4. Overall, all three textbooks include cases that may seem relevant because of their content, but which have not been cited by

${ }_{23}$ Aghdgomelashvili and Fapadridze v. Georgia App no 7224/II (ECtHR, 3 December 20I3).

${ }^{24}$ It should be mentioned that the last section of all three textbooks account for the case law under Article I2, where some also involve Article I4 and other do not. 
the ECtHR and which therefore have not had any obvious impact on the ECtHR's practice in the field. ${ }^{25}$

We turn now to the cases that do fall within the network, but have a very low in-degree rating. One such example is a case referred to by the French and the UK textbooks, namely National \&o Provincial Building Society $v U K .{ }^{26}$ The National of Provincial Building Society case has an in-degree rating of o in the Article I4 network, meaning that from 1997 up to the closing date for the network in 2OI4, the ECtHR had not made a single reference to it when making a decision in this area. The National of Provincial Building Society case concerned tax legislation with retroactive effect combined with a differential effect of new law on different building societies depending on various circumstances. This legislation triggered consideration of, among other things, the 'relevantly similar' principle relevant to Article I4. The fact that an issue has been considered in a case, however, is not the same as saying that the judgment actively influences the ECtHR's case law in regard to the issue in question. Since the ECtHR almost always cites relevant previous cases as part of its legal reasoning, it is unlikely that National \& Provincial Building Society has played any role in shaping the ECtHR's case law. A good reason why the case has not been cited in subsequent cases could well be that the case is atypical for issues of non-discrimination. Indeed, the domestic legislation in the case is very specific and not typical for the kind of issues that is normally dealt with under the prohibition against discrimination. This does not make the case wholly irrelevant of course, but it does seem somewhat inappropriate to include the case in a textbook presentation, whose aim is to capture the larger and more general picture of things.

We see further that each of the accounts refers to a substantial number of cases that have an in-degree number of o, meaning that they have not been cited by the ECtHR a single time in its subsequent adjudication and consequently must be considered to have no citation impact and hence only a very questionable role in developing the ECtHR's case law. In the French textbook, 8 cases referred to have an in-degree score of o, the UK textbook

\footnotetext{
${ }^{25}$ See footnote $\mathrm{I}$.

${ }^{26}$ National \& Provincial Building Society, Leeds Permanent Building Society and Yorkshire Building Society v. UK App no 21319/93, 21449/93 and 21675/93 (ECtHR, 23 October 1997).
} 
uses 7 such cases, and the German textbook refers to 30 cases that have indegree o, i.e. $20 \%$ of the total number of cases (144) to which the German textbook refers. In other words, if we assume that references to and citations of cases represent case-importance, $20 \%$ of the cases used by the German textbook have not been considered relevant for the ECtHR itself to cite.

\section{Omission of fudgments with a High In-degree Rating}

Another way of considering how useful a network approach is for legal analysis is to pose the following question: how do legal scientists as well as practitioners ensure that they grasp which cases are important within the jurisprudence of a court? In other words, how can we see the case law as a court itself sees it? One method is to consider those judgments that a court itself cites most frequently. We can capture this when we examine the data made available from the network and by studying all the cases with a high indegree rating.

Omitting the most frequently used cases from an account of the law raises question about the accuracy of the account. There are examples of such omissions in the textbooks with which we are comparing the results of network analysis. Of the most frequently cited judgments in the overall Article 14 network, there are 17 with an in-degree rating of $40+$. Of these, 8 are not included in any of the textbooks (two judgments are only included in one of the textbooks): 


\begin{tabular}{l|l} 
Judgment & In-degree rating \\
\hline Ireland v. UK (1978) & 86 \\
\hline Kaya v. Turkey (1998) & 62 \\
\hline Akdivar and Others v. Turkey (1996) & 69 \\
\hline Yasa v. Turkey (1998) & $5 \mathrm{I}$ \\
\hline Tanrikulu v. Turkey (1999) & 48 \\
\hline $\begin{array}{l}\text { Fames and Others v. UK (1986) } \\
\text { (only included in French textbook) }\end{array}$ & 47 \\
\hline Cakici v. Turkey (1999) & 46 \\
\hline Willis v. UK (2002) & \\
(only included in German textbook) & 45
\end{tabular}

Figure 5.8 high-degree omitted cases

A reading of the cases shows that they can be divided into two groups: those cases in which Article I 4 was 'absorbed' by one of the primary provisions and those cases where there was a specific decision on whether there was discrimination. The first category includes Ireland v. $U K^{27}$, Kaya $^{28}$, Akdivar ${ }^{29}$, Yasa ${ }^{30}$, Tanrikulu v. Turkey ${ }^{31}$ and Cakici v. Turkey ${ }^{32}$. These cases are of only peripheral relevance to the law on discrimination and their high in-degree rating is largely due to reciprocal citing within the clusters to which they belong. ${ }^{33}$ Hence, the reason these cases are not included in the textbook

${ }^{27}$ Ireland v. UK App no 5310/7I (ECtHR, I3 December 1977).

${ }^{28}$ Kaya v. Turkey App no 22535/93 (ECtHR, 28 March 2000).

${ }_{29}$ Akdivar and Others v. Turkey App no 21893/93 (ECtHR, I6 September 1996).

${ }^{30}$ Yasa v. Turkey App no 63/1997/847/I054 (ECtHR, 2 September 1998).

31 Tanrikulu v. Turkey App no 23763/94 (ECtHR, 8 July 1999).

${ }^{32}$ Cakici v. Turkey App no 23657/94 (ECtHR, 8 July 1999).

33 These mainly concern breaches of Article 2 and primarily involve cases brought against Turkey. These cases often include claims of breaches of Article I4 but most of them are decided on the basis of Article 2. Still, the brevity with which the Article $\mathrm{I} 4$ is dealt with in these cases may be a point in itself. See in this regard Henrik Palmer Olsen and Aysel Kücuksu, 'Finding Hidden Patterns in ECtHR's Case Law: On How 
accounts of discrimination law is that they mostly are considered to have little to do with Article I4. ${ }^{34}$

The two remaining judgments on the list above contain more detailed and substantive decisions on questions that are relevant for Article 14 and are therefore more significant for the development of the case law in this area. On the basis of the in-degree rating and their legal content, these judgments seem to be significant for the development of the law on discrimination but are nevertheless ignored by the textbook authors.

The first case is fames and Others $v$. $U K$ (I986) ${ }^{35}$, which concerned a legislative reform providing tenants with long-term leases with a right to buy the property they leased. As the legislation only affected landlords who had granted long-term leases, the applicants alleged that the legislation was discriminatory and therefore a breach of Article I4 in conjunction with Article I of Protocol I (art I4+PI-I). While the ECtHR concluded that the legislation was sufficiently generally expressed not to be discriminatory, the ECtHR simultaneously and importantly approximated its stand on 'reverse' discrimination by holding that laws aiming at providing a higher level of social protection to more vulnerable groups of citizens are not discriminatory within the meaning of the Convention, even though such regulations might discriminate against better-off citizens. This principle serves as an important clarification of the meaning of Article I4.

The other case that is not included in the French and the UK accounts (only in Europäische Menschenrechtskonvention) is Willis v. UK (2OO2) $)^{36}$. This case concerned payment of a widower's pension where, under national law, a widower was not entitled to the same support as a widow. The ECtHR ruled

Citation Network Analysis Can Improve Our Knowledge of ECtHR's Article I4 Practice' (2017) I7 International Journal of Discrimination and the Law 4.

34 This illustrates that while the judgments included in the network have been selected because there is a reference to Article I4 in the judgment, this does not mean that they have the same legal value in relation to Article I4; see section 2 above. It is necessary to combine the quantitative analysis of citations with a more qualitative analysis of the main points of the content of the judgments in order to obtain a more nuanced picture of the legal content of the individual cluster.

35 Fames and Others v. UK App no 8793/79 (EctHR, 2I February 1986).

${ }^{36}$ Willis v. UK App no 36042/97 (ECtHR, II June 2002). 
that there was discrimination based on sex. The French and the UK textbooks do not refer to the Willis case but refer instead to the Van Raalte $v$. Netherlands case (I997). ${ }^{37}$ Van Raalte concerned a tax exemption for childless women over the age of 45 , which was not available to men of the same age in the same situation. In Van Raalte, the ECtHR ruled that there was discrimination. Both cases were decided pursuant to Article I4 of the Convention and Article I of its Protocol No I and both cases concerned sex discrimination. Thus, if the intention was merely to give an example of the ECtHR's treatment of cases of sex discrimination under Article I4 of the Convention and Article I of Protocol No I, it does not matter which case is referred to.

However, there is a more significant and principled difference between these two cases. While both are examples of sex discrimination in connection with Article I of Protocol No I, they are not so similar that a reference to the one can in all circumstances be substituted by a reference to the other. There is a difference between whether Article I4 is applicable to the payment of welfare benefits (Willis) or to tax law (Van Raalte) and in this connection it is relevant that the ECtHR frequently considers the scope of Article I4 through the 'ambit' test. From this perspective, there is a question of whether the ECtHR has developed a rule and whether the same rule was applied in both cases. The textbooks do not elaborate on this point.

None of the accounts elaborate on how the judgments they use have been selected and what their status in the overall network is in terms of their role in the legal development of the ECtHR's case law; instead, the cases are generally presented as examples, seemingly all with an equal weight. In omitting information about the ECtHR's citation practice, one also omits relevant information about the different role various judgments may have in the ECtHR's case law as a whole. Furthermore, this may also introduce a degree of randomness into the account of what the law is. Omitting cases that are most used by the ECtHR is equivalent to disregarding the cases that the ECtHR itself considers the most relevant cases to cite in support of its decisions. Similarly, including cases with o or very low in-degree is equivalent to disregarding the fact that these cases have not ever been actively cited by the ECtHR, which indicates that they have not played any explicit role in the

37 Van Raalte v. The Netherlands App no 20060/92 (ECtHR, 2I February 1997). 
ECtHR's development of Article I4 law. Citing such low impact cases may at worst be misleading, because they could represent reasoning that has subsequently been abandoned by the ECtHR.

The general conclusion we can draw from the investigations above is that network analysis can enrich an account of the law by making ECtHR's use of its own case law visible. The data that form the basis for network analyses can both identify cases that are frequently applied by the ECtHR and reveal which cases have little or no significance in the ECtHR's case law practice, despite the references to them in the legal literature.

\section{Interim Conclusion on In-degree Ratings}

One of the ways in which network analysis can help enrich a legal analysis is by making it possible to identify the cases that are actively used in the practice of the ECtHR to support its judgments, rather than merely listing a range of judgments of variable relevance in practice. This is useful for any lawyer because it must be expected that, all else being equal, a legal argument will be more persuasive if it is based on references to cases which the ECtHR itself explicitly recognises as relevant in its judgments.

In an educational context, it will strengthen legal teaching if students learn to relate to knowledge about citation impact and network analysis, rather than learning about the ECtHR's decisions simply as a range of (random?) examples of how the Convention can be applied. This could sharpen the students' critical thinking skills and lead to a better and more dynamic understanding of how the ECtHR operates.

The European law on human rights is, to a high degree, based on case law. As case law is dynamic and constantly changing, it is important that accounts of human rights law are based on judgments that the ECtHR itself considers to be the weightiest cases to cite - based on its practice. If an account of the law relies on older judgments with low in-degree ratings and omits the cases with highest citation impact, there is a considerable risk that it will not give an accurate picture of the ECtHR's current view of the state of the law. 


\section{COMPARING LEGAL EXPERTISE}

A problem of legal doctrinal accounts of law is that they can be seen as being subjective in the sense that they emphasise case law that appears important to one author but not to another. This subjectivity is displayed in the diversity of cases included in different textbooks that all cover the same area of law. In the following developments, we compare the three textbooks with each other and with the network, we look into which cases the authors do and do not agree on, and we discuss what may explain the divergences. ${ }^{38}$

\section{Distribution of Cases}

First, we look at the distribution of cases between the textbooks and the network in order to gain an overview of the extent of overlaps, consensus and discord between the three textbooks and the ECtHR's own citations. Figure 6 displays the actual number and percentages of cases that appear within only one of the textbooks and the number of cases that are shared by the three textbooks.

${ }^{38}$ In the following section we again deliberately avoid use of the term 'precedent'. It should be noted that when legal textbook authors cite cases, they presumably do so because they consider these cases to create precedent for the law they are cited for. Since, however, we avoid the term 'precedent' when describing citation patterns in our network, and instead use the term citation impact, we have decided to similarly avoid the term when analysing which cases our selected textbooks cite. 


\begin{tabular}{|c|c|c|c|c|}
\hline & \multirow{2}{*}{$\begin{array}{l}\text { Number } \\
\text { of cases }\end{array}$} & \multicolumn{3}{|c|}{ Percentage within each textbook } \\
\hline & & French & German & UK \\
\hline French textbook only & 24 & $27 \%$ & & \\
\hline $\begin{array}{l}\text { German textbook } \\
\text { only }\end{array}$ & 64 & & $44 \%$ & \\
\hline UK textbook only & 23 & & & $23 \%$ \\
\hline French + German & I3 & $14 \%$ & $9 \%$ & \\
\hline French + UK & $\mathrm{I} 2$ & $13 \%$ & & $12 \%$ \\
\hline German + UK & 27 & & I8\% & $26 \%$ \\
\hline All textbooks & $4 \mathrm{I}$ & $46 \%$ & $29 \%$ & $39 \%$ \\
\hline $\begin{array}{l}\text { Total } \\
(\mathrm{N})\end{array}$ & & $\begin{array}{l}\text { IOO\% } \\
(90)\end{array}$ & $\begin{array}{l}\text { IOO\% } \\
(\mathrm{I} 44)\end{array}$ & $\begin{array}{l}\mathrm{IOO} \% \\
(\mathrm{IO} 3)\end{array}$ \\
\hline
\end{tabular}

Figure 6. Distribution of cases in textbooks and network

The first three rows show the cases that appear only in one textbook (note that they can also appear in the network, but the interest here is where there is no overlap between the three textbooks). We see that 24 cases in the French textbook appear only in that textbook, equivalent to $27 \%$ of all the cases referred to in the French textbook. In the German textbook, 64 cases appear only there, equivalent to $44 \%$ of all the cases referred to in that textbook. The UK textbook contains 23 cases that are not used by the two other textbooks, equivalent to $23 \%$ of the cases mentioned in that textbook.

In the following three rows (called French+German, French+UK, German $+\mathrm{UK}$ ), we see the overlaps between the textbooks in actual numbers and in percentages. The French and German textbooks have 13 cases in common, the French and the UK textbook have 12 cases in common and the German and the UK textbook share references to 27 cases. Reading the table from the columns at the top (called French, German and UK textbooks), we can see that the French textbook shares $14 \%$ of its judgments with the German textbook and another $13 \%$ with the UK textbook. In the German textbook, $9 \%$ of the cases overlap with the French and I8\% with the UK 
textbook. Finally, in the UK textbook, $\mathrm{I}_{2} \%$ of the cases used are shared with the French textbook, while $26 \%$ of cases are shared with the German. It should be noted that the total number of cases varies between the textbooks and that this fluctuation of course influences the relative differences when we compare across the textbooks.

The German textbook has more cases in common with the UK than with the French textbook. Likewise, the UK textbook has more in common with the German than with the French. Nonetheless, from these overlaps it cannot be inferred that any of the textbooks is an outlier and that the others have significantly more cases in common.

While these numbers show the proportion of cases exclusive to each textbook, the opposite figures, i.e. the proportion of shared cases between all textbooks in each of the textbooks, are found in the row called 'all textbooks'. Here we see that the French textbook has the highest proportion (45\%) of cases that also appear in the other textbooks. Of the cases referred to in the UK textbook, $39 \%$ are also found in both of the other textbooks. The German textbook has the lowest proportion of cases shared with the other two, namely $28 \%$ (again it should be remembered that absolute numbers differ).

This distribution of cases in the textbooks and the network, and the overlaps between these datasets is also illustrated in figure 7 (below). 


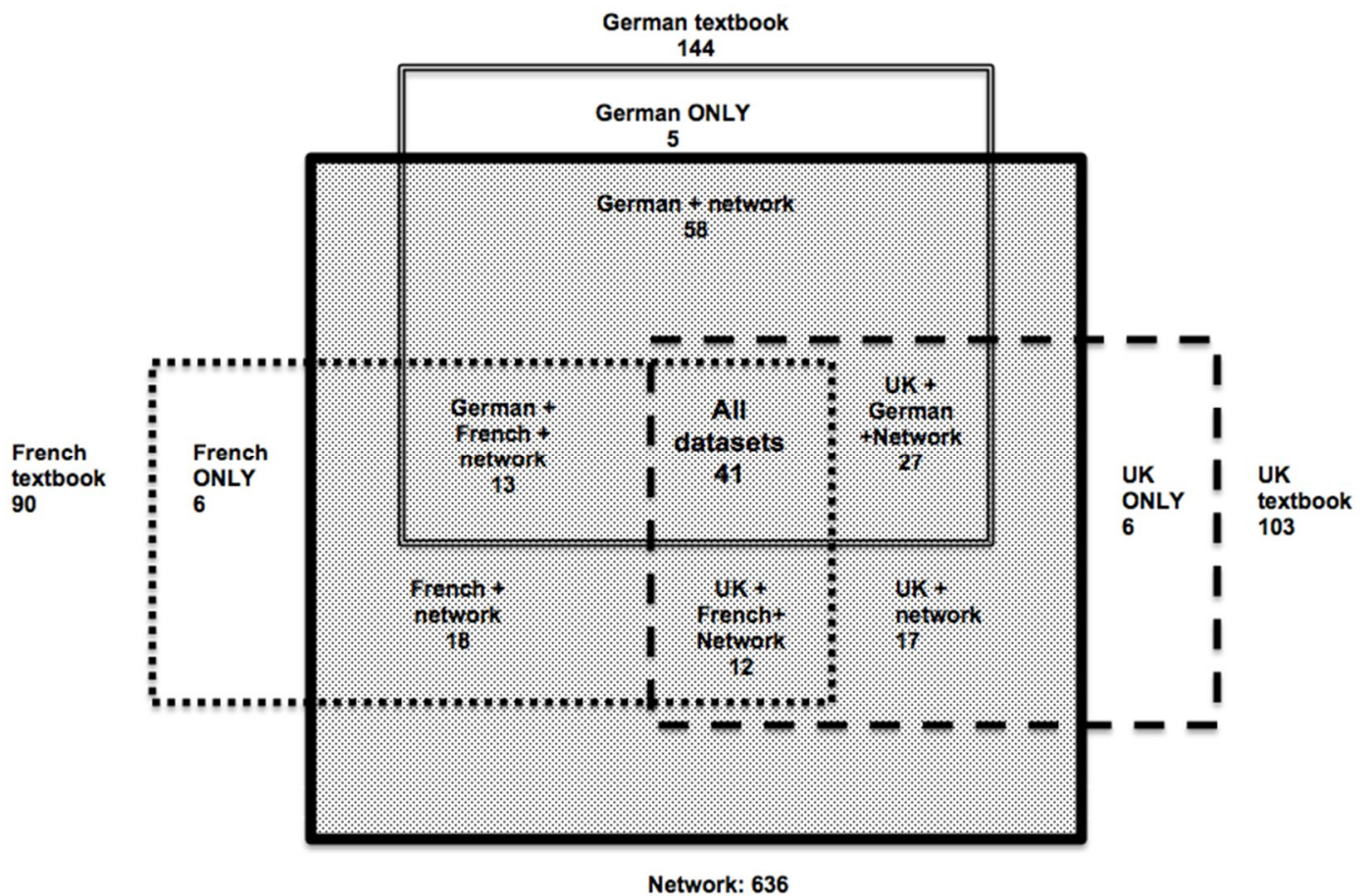

Figure 7. Proportion of case distribution

By drawing the distribution of cases in the textbooks, in the network, and the overlaps, it becomes clear that quite a large proportion of the referenced cases appear exclusively in one single textbook. In other words, there are some cases on which the textbooks do not converge, but which only appear in one of the textbooks (and the network). These are the cases, which in the graph are within the squares called, for example, 'French ONLY' (these are the cases outside the network) or French+Network. There are 24 such cases in the French textbook, 23 in the UK textbook and 64 in the German textbook.

The 4I cases in the box called 'All datasets' in the centre of the graph constitute the overlap between all three textbooks and the network. These cases represent agreement between all three textbooks and the network and we call these the 'consensus cases'.

\section{The Consensus Cases}

The 4I consensus cases that appear in all three textbooks as well as in the network are the following: 


\begin{tabular}{|c|c|c|}
\hline No. & 'Consensus cases' in 3 textbooks + network & In-degree \\
\hline I & 5IOI/7I Engel and Others v. the Netherlands & 29 \\
\hline 2 & 6833/74 Marckx v. Belgium & 60 \\
\hline 3 & 7525/76 Dudgeon v. The United Kingdom & 36 \\
\hline 4 & 8695/79 Inze v. Austria & 38 \\
\hline 5 & $8777 / 79$ Rasmussen v. Denmark & 34 \\
\hline 6 & 8919/80 Van Der Mussele v. Belgium & I4 \\
\hline 7 & 9214/80 Abdulaziz and Others v. The United Kingdom & 49 \\
\hline 8 & II58I/85 Darby v. Sweden & IO \\
\hline 9 & I2875/87 Hoffmann v. Austria & $\mathrm{I} 2$ \\
\hline IO & I3580/88 Karlheinz Schmidt v. Germany & 34 \\
\hline II & I45I8/89 Schuler-Zgraggen v. Switzerland & 15 \\
\hline $\mathrm{I} 2$ & I6213/90 Burghartz v. Switzerland & I4 \\
\hline I3 & 17371/90 Gaygusuz v. Austria & 46 \\
\hline I4 & 20060/92 Van Raalte v. The Netherlands & 44 \\
\hline 15 & $22083 / 93$ Stubbings and Others v. The United Kingdom & I4 \\
\hline I6 & 28369/95 Camp and Bourimi v. the Netherlands & 25 \\
\hline $\mathrm{I} 7$ & 33290/96 Salgueiro da Silva Mouta v. Portugal & I6 \\
\hline I8 & 36515/97 Frette v. France & 25 \\
\hline I9 & 34369/97 Thlimmenos v. Greece & 47 \\
\hline 20 & 400I6/98 Karner v. Austria & 16 \\
\hline $2 \mathrm{I}$ & 43577/98 Nachova and Others v. Bulgaria & 35 \\
\hline 22 & 45330/99 S.L. v. Austria & 9 \\
\hline 23 & 53760/oo B.B. v. The United Kingdom & $\mathrm{O}$ \\
\hline 24 & 55523/oo Angelova and Iliev v. Bulgaria & 2 \\
\hline 25 & 57325/oo D.H. and Others v. the Czech Republic & 45 \\
\hline 26 & 68864/or Merger and Cros v. France & 5 \\
\hline 27 & 65900/or Stec and Others v. The United Kingdom & 57 \\
\hline 28 & I7209/02 Zarb Adamiv. Malta & 22 \\
\hline 29 & I3IO2/O2 Kozak v. Poland & 5 \\
\hline 30 & I8984/O2 P.B. and F.S. v. Austria & 3 \\
\hline $3 \mathrm{I}$ & I5766/03 Orsus and Others v. Croatia & 6 \\
\hline 32 & 5335/05 Ponomaryovi v. Bulgaria & 3 \\
\hline 33 & I3378/05 Burden \& Burden v. The United Kingdom & 43 \\
\hline 34 & 27996/o6 Sejdic and Finci v. Bosnia and Herzegovina & $\mathrm{I} 2$ \\
\hline 35 & 30078/o6 Konstantin Markin v. Russia & IO \\
\hline 36 & I9010/o $7 X$ and Others v. Austria & 6 \\
\hline 37 & 7798/o8 Savez Crkava Rijec Zivota and Others v. Croatia & 3 \\
\hline 38 & 2938I/o9 Vallianatos and Others v. Greece & 3 \\
\hline 39 & 48420/Io Eweida and Others v. The United Kingdom & 4 \\
\hline 40 & I6574/o8 Fabris v. France & 3 \\
\hline $4 \mathrm{I}$ & 3564/II Eremia v. The Republic of Moldova & 2 \\
\hline
\end{tabular}

Figure 8. List of consensus cases 
What do all these cases have in common, apart from the fact that they all concern discrimination issues under Article I4 in one way or another? ${ }^{39}$ Some data can be easily examined without going into the details of each case.

Firstly, in the table above, the cases are ordered according to time. This chronology shows that the $4 \mathrm{I}$ consensus cases are spread over exactly $4 \mathrm{O}$ years..$^{40}$ It appears that the number of consensus cases grows over the decades: there are 5 consensus cases from the I 970 , 6 from the I980s, II from the 1990 s and 18 from the 2000 s. This growth can be read as an agreement on the inclusion of more recent cases as important for an accurate account of the development of the law under Article I4. Furthermore, the consensus cases are spread more-or-less evenly over the years from I990 to 20 II with only few exceptions (there are no cases from I99I, I994 and 2004). We consider this to indicate a shared logic among the legal experts concerning how to account for the law in a given legal domain, namely to portray the law through its incremental and temporal development as more and more cases are decided.

The fact that 5 cases lodged at the ECtHR in the I97os are included, despite the fact that these cases are unlikely to represent the current state of the law under ArticleI4, may be due to the fact that these cases are considered to have

39 Among these are some cases that are very likely to form part of many human rights lawyers' knowledge of the law of the European Convention of Human Rights. The cases cover different aspects of Article I 4 broadly, as represented by for example Engel and Others $v$. The Netherlands on discrimination on grounds of status (in the military), Marckx $v$. Belgium, which deals with Article I4 in relation to distinctions between legitimate and illegitimate family, Rasmussen $v$. Denmark on discrimination on grounds of sex in relation to paternity leave, Abdulaziz, Cabales and Balkandali v. UK finding a violation of Article I4 with Article 8 without a separate violation of a substantive article in the Convention, D.H. and others v. The Czech Republic on indirect discrimination with regard to the right to education (PI-2), Frette v. France on alleged discrimination on grounds of (homo)sexuality, Thlimmenos $v$. Greece on discrimination on the grounds of religion and Stec and Others $v$. UK on state pensions and discrimination between men and women.

$4^{\circ}$ Note that the cases are identified by their application number in ECHR's database HUDOC, which means that the year therein denotes when the case was logged in the ECtHR's system and the year and date of the delivery of the judgment in the case is approximately 5 year later. While this is not optimal for an analysis of the temporality of the cases, it is the application number which is the identification metric of cases under ECHR and also how cases refer to other cases. 
a somewhat emblematic status for Article I4. As very early cases they could be considered to have set the first and most important direction for the ECtHR and to have clarified basic meanings in the wording of Article I4. This can explain their presence in the textbooks.

The consensus cases also cover a broad range of different responding states against which the claims have been brought. Austria and the UK are the most prominent with 7 cases each, while France is only represented with 2 cases. This should be seen in light of statistics from the Council of Europe (CoE) on the ratio of cases establishing a violation of Article I4 for each CoE Member State. These statistics show that the UK has historically set the record and has been found to violate Article 14 in 44 cases in the years from 1959 to $2016 .{ }^{4 \mathrm{I}}$ Interestingly, Austria comes second with 26 judgments concluding a violation of Article I4, while Germany has only been found to violate Article I 4 in 12 cases. Hence, even if these statistics only include violations and not all Article I4 cases as such, it appears that the statistics are reflected in the consensus cases.

If we turn to the case law citation network and the in-degree score, what can this ranking reveal about the agreement between the textbooks on the consensus cases? In-degree score is the network metric indicating the number of times the ECtHR itself has cited the case in later judgments. Therefore, the question here is whether the consensus cases reflect a shared understanding of case-importance between legal experts in academia and legal experts at the courts. Considering the in-degree ranking of the consensus cases, this does not appear to be the case, because the in-degree score varies considerably, from o to 6o, between the consensus cases. Most of the cases from the early period have a relatively high in-degree and all cases until 1998 have an in-degree above Io, some up to 60. The average in-degree among the consensus cases in this period is 28. Around the turn of the millennium, the in-degree starts to decrease, the average degree being II. Naturally, the earlier cases have longer to 'collect' references, which may partly explain their higher in-degree scores. Yet, the list also shows that an accumulation of references over a longer period of time is not always the

${ }^{4 \mathrm{r}}$ Council of Europe, 'Violation by Article and by States (I959-2016)' <http://www.echr.coe.int/Documents/Stats_violation_1959_20I6_ENG.pdf> accessed 9 August 2018. 
explanation for a high in-degree. For example, the case of Stec and Others $v$. The United Kingdom (200I) ${ }^{42}$ has an in-degree of 57 , while Burden v. UK (2005) ${ }^{43}$ has an in-degree of 43.

One of the most intriguing parts of our study is the finding that while there is agreement between the three textbooks on the judgments that are authoritative, from the earliest activity of the ECtHR until the end of the last decade, there is also agreement on the importance of some cases which have never or hardly ever been used by the ECtHR itself. For example, all three textbooks refer to the cases of B.B. v. UK (2004) $)^{44}$ Anguelova and Iliev v. Bulgaria (2007) ${ }^{45}$ and Eremia $v$. The Republic of Moldova $(2013)^{46}$, all of which have in-degree scores between o and 2. We will take a closer look at these cases and how they are used in the textbooks.

In all three textbooks, Eremia v. The Republic of Moldova is used as a primary example of the ECtHR's practice with regard to gender-based violence as a form of discrimination against women. The case of Anguelova and Iliev v. Bulgaria is used in the French and UK textbook as one of a number of examples to show the particular demand by the ECtHR for contracting states to effectively investigate offences or attacks involving racial hatred. The same case is used in the German textbook to illustrate the ECtHR's practice of examining Article I4 even if a violation of a substantive article has already been found, in this case discrimination based on ethnicity (Articler4+Article2), and, in addition, to demonstrate the ECtHR's method for determining discrimination as also involving the consideration of different situations that are treated the same (as opposed to relevantly similar situations that are treated differently). B.B. v. UK is used in both the French and the UK textbook as one of several cases illustrating the practice that very weighty reasons are required for justification of discrimination on grounds of sexual orientation. In the German textbook, it is referred to in regard to sex

\footnotetext{
$4^{2}$ Stec and Others v. UK App no 65900/or (ECtHR, 26 May 2006).

43 Burden v. UK App no 13378/05 (ECtHR, 29 April 2008).

44 B.B. v. UK App no 53760/oo (ECtHR, Io February 2004).

45 Anguelova and Iliev v. Bulgaria App no 55523/00 (ECtHR, 26 July 2007).

${ }^{46}$ Eremia v. The Republic of Moldova App no 3564/II (ECtHR, 28 May 2013).
} 
and age discrimination and the scope of the margin of appreciation the state has in relation to age discrimination.

The textbooks seem to agree that these cases are relevant to Article I4 case law, even if they have hardly ever been cited by the ECtHR. This raises the question of whether the textbooks give wrong or biased information about the law or whether it shows the limitation of citation network analysis as a legal method. In our view, there is no clear answer to that question, but as we shall argue below, we believe there are good arguments to be sceptical of the textbooks.

In regard to Eremia, the case is so recent ${ }^{47}$ that it has scarcely had time to be cited by subsequent cases. As discussed earlier (see section 2.2. above), it therefore remains unclear whether this case will become an important case in regard to Article I4 in conjunction with Article 3 (as judged in 2014). Moreover, a qualitative analysis of the case shows that there is an earlier case - Opuz v. Turkey $4^{8}$ issued in 2009 - which has essentially the same legal content and which is cited in a way that suggests that that case is (still) the leading reference for Article 14 in conjunction with Article 3 in relation to domestic violence against women.

In regard to Anguelova, a separate study has identified a whole series of cases that deal with Article 14 in conjunction with Article 2 in relation to racially/ethnically motivated crime and the investigation of such crimes. ${ }^{49}$ That study found 28 judgments in this serie of cases, many of which were cited more than Anguelova and several which were more recent (Anguelova was issued in 2002). Nachova and others v. Bulgaria5 ${ }^{50}$ for example is both more recent (from 2005) and more highly cited.

Finally, in regard to $B B v . U K$, it is worth noting that this case is atypical in that the UK government conceded to having violated Article I4 in conjunction with Article 8, as already established in an earlier case (Sutherland

\footnotetext{
47 The judgment is from 2013. The network analysis contains judgments until the end of 20I4; the textbooks are published in 20I4, 2015 and 2016 respectively.

$4^{8}$ Opuz v. Turkey App no 334OI/o2 (ECtHR, 9 June 2009).

49 Palmer Olsen and Kücuksu (n 33).

$5^{\circ}$ Nachova and others v. Bulgaria App no 43577/98 and 43579/98 (ECtHR, 6 July 2005).
} 
v. $U K^{51}$, issued in 2OOI). It therefore seems quite obvious why the ECtHR would not cite $B B$ : the case is essentially about what kind of compensation the applicant should receive, not about Article I4 as such.

In sum, the study of the cases on which there is consensus among the three textbooks makes it possible to infer two points. Firstly, we see agreement about the importance of cases from the earliest period of the ECtHR's activity to the present. Hence, looking at the references of the textbooks shows that legal experts seem to have an understanding of the law based on the temporal development of case law and that some cases appear to be perceived as emblematic in this development under Article I4 ECHR. Secondly, comparing the consensus cases to the network measures also shows that legal experts sometimes cite the same cases even though those cases have a very low in-degree. In the following section we look into the opposite, the cases about which the textbook authors do not agree.

\section{The Discord Cases}

There is a surprisingly large number of cases which are used by only one of the textbooks. As mentioned above, these cases can be termed the 'discord cases'. The question in regard to the discord cases is whether the difference between the textbooks can be explained, for example through a nationality bias of the authors or some other such difference between the authors or their audience. The discord cases are presented in figure 9 (below).

${ }^{51}$ Sutherland v. UK App no 25186/94 (ECtHR, 27 March 200I). 


\begin{tabular}{|c|c|c|c|c|c|}
\hline \multicolumn{2}{|c|}{ French textbook only } & \multicolumn{2}{|c|}{$\begin{array}{l}\text { German textbook } \\
\text { only }\end{array}$} & \multicolumn{2}{|c|}{ UK textbook only } \\
\hline $4464 / 70$ & $\begin{array}{l}\text { National Union and } \\
\text { Belgian Police v. } \\
\text { Belgium }(20)\end{array}$ & $6538 / 74$ & $\begin{array}{l}\text { The Sunday Times } \\
\text { v. The UK (No. I) } \\
\text { (3) }\end{array}$ & $5095 / 7 \mathrm{I}$ & $\begin{array}{l}\text { Kjeldsen, Busk } \\
\text { Madsen and Pedersen } \\
\text { v. Denmark (2I) }\end{array}$ \\
\hline $6289 / 73$ & Airey v. Ireland (30) & $9562 / 8 \mathrm{I}$ & $\begin{array}{l}\text { Monnell And } \\
\text { Morris v. The UK } \\
\text { (3) }\end{array}$ & $9063 / 80$ & $\begin{array}{l}\text { Gillow v. The UK } \\
\text { (8) }\end{array}$ \\
\hline $8793 / 79$ & $\begin{array}{l}\text { Fames and Others } v . \\
\text { The UK (47) }\end{array}$ & $\mathrm{I} 2742 / 87$ & $\begin{array}{l}\text { Pine Valley } \\
\text { Developments Ltd } \\
\text { v. Ireland (37) }\end{array}$ & I6I63/90 & $\begin{array}{l}\text { Eugenia Michaelidou } \\
\text { Developments Ltd v. } \\
\text { Turkey (I) }\end{array}$ \\
\hline $9006 / 80$ & $\begin{array}{l}\text { Lithgow v. The UK } \\
(3 \mathrm{I})\end{array}$ & $19823 / 92$ & $\begin{array}{l}\text { Hokkanen v. } \\
\text { Finland- }\end{array}$ & $25088 / 94$ & $\begin{array}{l}\text { Chassagnou. France } \\
\text { (35) }\end{array}$ \\
\hline I $2849 / 87$ & $\begin{array}{l}\text { Vermeire v. Belgium } \\
\text { (4) }\end{array}$ & $31417 / 96$ & $\begin{array}{l}\text { Lustig-Prean And } \\
\text { Beckett v. The UK } \\
\text { (I4) }\end{array}$ & $25186 / 94$ & $\begin{array}{l}\text { Sutherland v. The } \\
\text { UK (4) }\end{array}$ \\
\hline $21794 / 93$ & C. v. Belgium (I) & $34045 / 96$ & $\begin{array}{l}\text { Hoffmann v. } \\
\text { Germany (o) }\end{array}$ & $2578 \mathrm{I} / 94$ & $\begin{array}{l}\text { Cyprusv. Turkey } \\
\text { (I8) }\end{array}$ \\
\hline $21439 / 93$ & Botta v. Italy (6) & $30943 / 96$ & $\begin{array}{l}\text { Sabin v. Germany } \\
\text { (I8) }\end{array}$ & $27824 / 95$ & $\begin{array}{l}\text { Posti and Rabko v. } \\
\text { Finland (4) }\end{array}$ \\
\hline $21986 / 93$ & Salman v. Turkey - & $36677 / 97$ & $\begin{array}{l}\text { S.A. Dangeville v. } \\
\text { France (3) }\end{array}$ & $36983 / 97$ & $\begin{array}{l}\text { Haas v. The } \\
\text { Netherlands (I) }\end{array}$ \\
\hline $24746 / 94$ & $\begin{array}{l}\text { Hugh fordon v. The } \\
\text { UK (I9) }\end{array}$ & $34462 / 97$ & $\begin{array}{l}\text { Wessels-Bergervoet } \\
\text { v. The Netherlands } \\
\text { (o) }\end{array}$ & $42949 / 98$ & $\begin{array}{l}\text { Runkee and White v. } \\
\text { The UK (7) }\end{array}$ \\
\hline $28135 / 95$ & Magee v. The UK (3) & $36042 / 97$ & $\begin{array}{l}\text { Willis v. The UK } \\
\text { (45) }\end{array}$ & $71156 / 01$ & $\begin{array}{l}\text { Members of fehovas } \\
\text { Witnesses v. Georgia } \\
\text { (4) }\end{array}$ \\
\hline $43208 / 98$ & $\begin{array}{l}\text { Perkins and } R v \text {. The } \\
U K(\mathrm{I})\end{array}$ & $4 \mathrm{I} 488 / 98$ & $\begin{array}{l}\text { Velikova v. } \\
\text { Bulgaria (I9) }\end{array}$ & $42949 / 98$ & $\begin{array}{l}\text { Runkee and White v. } \\
\text { The UK (7) }\end{array}$ \\
\hline $74832 /$ I & $\begin{array}{l}\text { Mizigarovav. } \\
\text { Slovakia (I) }\end{array}$ & $40892 / 98$ & $\begin{array}{l}\text { Koua Poirrez v. } \\
\text { France (8) }\end{array}$ & $13624 / 03$ & $\begin{array}{l}\text { Koky and Others v. } \\
\text { Slovakia - }\end{array}$ \\
\hline $70665 / 01$ & $\begin{array}{l}\text { Rainys b } \\
\text { Gasparavisius v. } \\
\text { Lithuania (2) }\end{array}$ & $40825 / 98$ & $\begin{array}{l}\text { Religionsgemeinsch } \\
\text { aft Der Zeugen } \\
\text { fehovas And } \\
\text { Others v. Austria } \\
\text { (8) }\end{array}$ & $\mathrm{I} 2050 / 04$ & Mangouras v. Spain \\
\hline $7 \mathrm{II} 27 / \mathrm{OI}$ & $\begin{array}{l}\text { Bevacqua v. } \\
\text { Bulgaria- }\end{array}$ & $42967 / 98$ & $\begin{array}{l}\text { Löffelmann v. } \\
\text { Austria (2) }\end{array}$ & $4 \mathrm{I} 49 / 04$ & Aksu v. Turkey (2) \\
\hline $42722 / 02$ & $\begin{array}{l}\text { Stoica v. Romania } \\
(7)\end{array}$ & $46720 / 99$ & $\begin{array}{l}\text { Fabn And Others } \\
\text { v. Germany (8) }\end{array}$ & I5966/04 & $\begin{array}{l}\text { I.G. and Others v. } \\
\text { Slovakia - }\end{array}$ \\
\hline $2660 / 03$ & $\begin{array}{l}\text { Hajduovav. } \\
\text { Slovakia- }\end{array}$ & $49686 / 99$ & Gutl v. Austria (2) & $21906 / 04$ & $\begin{array}{l}\text { Kafkaris v. Cyprus } \\
\text { (6) }\end{array}$ \\
\hline $44803 / 04$ & $\begin{array}{l}\text { Petropoulou- } \\
\text { Tsakirisv. Greece (I) }\end{array}$ & $58453 / 00$ & $\begin{array}{l}\text { Niedzwieckiv. } \\
\text { Germany (3) }\end{array}$ & $26266 / 05$ & Raviv v. Austria (o) \\
\hline $24768 / 06$ & $\begin{array}{l}\text { Perdigao v. Portugal } \\
-\end{array}$ & $59140 / 00$ & $\begin{array}{l}\text { Okpisz v. Germany } \\
\text { (7) }\end{array}$ & $6339 / 05$ & $\begin{array}{l}\text { Evans v. The UK } \\
\text { (Io) }\end{array}$ \\
\hline $9106 / 06$ & $\begin{array}{l}\text { Genderdoc- } M v \text {. } \\
\text { Moldova- }\end{array}$ & $63684 / 00$ & $\begin{array}{l}\text { Hobbs, Richard, } \\
\text { Walsh And Geen } \\
\text { v. The UK (3) }\end{array}$ & $34848 / 07$ & $\begin{array}{l}\text { O'Donoghuev. The } \\
\text { UK (I) }\end{array}$ \\
\hline $4916 / 07$ & $\begin{array}{l}\text { Alekseyev v. Russia } \\
\text { (I) }\end{array}$ & 63106/00 & $\begin{array}{l}\text { Vasil Sashov } \\
\text { Petrov v. Bulgaria } \\
\text { (2) }\end{array}$ & I8968/07 & V.C. v. Slovakia - \\
\hline $33234 / 07$ & $\begin{array}{l}\text { Valiulienév. } \\
\text { Litbuania- }\end{array}$ & $77782 /$ oI & Luczak v. Poland & $448 \mathrm{I} 4 / 07$ & $\begin{array}{l}\text { Budak and Others } v . \\
\text { Turkey - }\end{array}$ \\
\hline
\end{tabular}




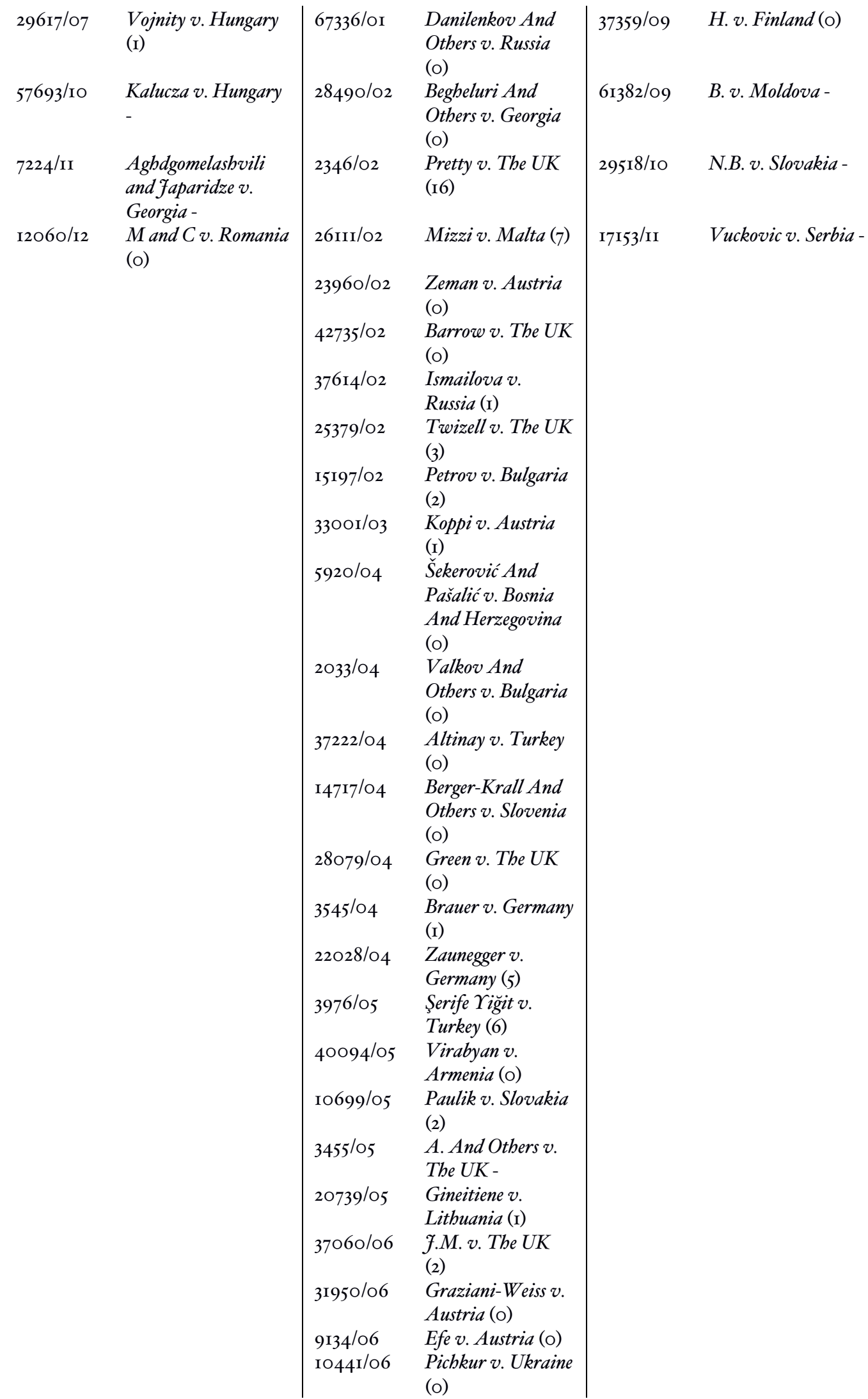




\begin{tabular}{|c|c|}
\hline I828/o6 & $\begin{array}{l}\text { G.I.E.M. S.R.L.v. } \\
\text { Italy - }\end{array}$ \\
\hline $44614 / 07$ & $\begin{array}{l}\text { Milanovic v. } \\
\text { Serbia (I) }\end{array}$ \\
\hline $5123 / 07$ & $\begin{array}{l}\text { Rangelov v. } \\
\text { Germany (o) }\end{array}$ \\
\hline 19508/07 & $\begin{array}{l}\text { Granos Organicos. } \\
\text { v. Germany (o) }\end{array}$ \\
\hline 31913/07 & $\begin{array}{l}\text { E.B. And Others v. } \\
\text { Austria (22) }\end{array}$ \\
\hline $4915 \mathrm{I} / 07$ & $\begin{array}{l}\text { Muñoz Díaz v. } \\
\text { Spain (2) }\end{array}$ \\
\hline $41615 / 07$ & $\begin{array}{l}\text { Neulinger And } \\
\text { Shuruk v. } \\
\text { Switzerland- }\end{array}$ \\
\hline I4480/O8 & $\begin{array}{l}\text { Tarkoev And } \\
\text { Others v. Estonia } \\
\text { (o) }\end{array}$ \\
\hline $6268 / 08$ & $\begin{array}{l}\text { Andrle v. The } \\
\text { Czech Republic (o) }\end{array}$ \\
\hline $46286 / 09$ & $\begin{array}{l}\text { Maggio And } \\
\text { Others v. Italy (2) }\end{array}$ \\
\hline $53124 / 09$ & $\begin{array}{l}\text { Genovese v. Malta } \\
\text { (o) }\end{array}$ \\
\hline $23338 / 09$ & $\begin{array}{l}\text { Kautzorv. } \\
\text { Germany (o) }\end{array}$ \\
\hline 4507I/09 & $\begin{array}{l}\text { Abrens v. } \\
\text { Germany (o) }\end{array}$ \\
\hline $755^{2} / 09$ & $\begin{array}{l}\text { The Church Of } \\
\text { Jesus Christ v. The } \\
\text { UK (I) }\end{array}$ \\
\hline I7966/10 & $\begin{array}{l}\text { Manzanas Martin } \\
\text { v. Spain (o) }\end{array}$ \\
\hline $38590 / 10$ & $\begin{array}{l}\text { Biao v. Denmark } \\
\text { (I) }\end{array}$ \\
\hline I939I/II & $\begin{array}{l}\text { Topčić-Rosenberg } \\
\text { v. Croatia (o) }\end{array}$ \\
\hline $64320 / 01$ & $\begin{array}{l}\text { Moldovan and } \\
\text { others v. Romania } \\
\text { (no. 2) - }\end{array}$ \\
\hline $37359 / 09$ & $\begin{array}{l}\text { Hämäläinen v. } \\
\text { Finland (judgment } \\
\text { from } 2015 \text { not in } \\
\text { network) }\end{array}$ \\
\hline
\end{tabular}

Figure 9. List of discord cases

The table displays the discord cases in chronological order. The cases for all three textbooks are spread more or less evenly over time. For all three textbooks, the first discord cases are in the I970s; about half are from before 2000 and the other half from after 2000 . It can quite quickly be confirmed that the discord cases cannot be explained on the basis of a different temporal focus in any of the textbooks. 
Can the discord cases be explained through a nationality bias in the textbooks, in the sense that the French textbook, for example, refers to more cases with France as the responding state? Or can other patterns regarding the states in the different discord cases be traced?

The French textbook's 25 discord cases involve 15 different states. Of these the UK appears most frequently, namely five times. This reflects the leading position of the UK as the state with most cases brought against it and, as France does not appear once in the French textbooks' list of discord cases, a nationality bias favoring the cases brought against France as illustrative for legal development can be ruled out.

The UK textbook contains references to 25 'discord' cases. These are distributed across 13 states and again we see that the UK appears most frequently ( 6 times). Nonetheless, the fact that 6 out of 25 cases are against the UK is not sufficient to infer that this reveals a nationality bias, since the UK is the state with most cases and violations found under Article I4.

The German textbook contains 66 discord cases, which is substantially more than the 25 discord cases in both the French and UK textbooks; moreover, these 66 discord cases represent $45 \%$ of the German textbook's total of I44 case references. Hence, $45 \%$ of the cases in the German textbook do not appear in either of the other two textbooks. The 66 discord cases concern 27 different states. However, there are certain states which are referred to frequently, namely the United Kingdom, with 12 references, as well as, interestingly, Germany, II times, and Austria, 7 times (27\% of the 66 discord cases together). This means that cases involving Germany and Austria are used more frequently in the German textbook than the two others. While it may be exaggerated to talk of a nationality bias in the German textbook, the weight of certain cases for a legal textbook raises questions concerning the purpose of the book. If the purpose of the textbook is to train lawyers in the German-speaking countries (Germany and Austria) to work within these jurisdictions, it may be reasonable to include in the textbook the history of the cases brought before the ECtHR from these jurisdictions. On the other hand, a deliberate overrepresentation of German cases may give a biased view of the ECtHR's practice. If accounts of law aim to show the law as it is practiced for all, not the law as it is to us, then overrepresentation may not be helpful. 
Turning to the in-degree score of the discord cases between the three textbooks, a few in each textbook stand out. Among the discord cases in the French textbook, five cases have a high in-degree. These are used to illustrate Article 14 as having no independent existence, the ambit test and statistical discrimination under Article I4. Concretely, Airey v. Ireland ${ }^{236}$ together with National Union and Belgium Police v. Belgium ${ }^{237}$ are used to illustrate that Article I4 is an accessory article to the other substantive articles in the Convention. When the author explains the ambit test, fames \& Others $v$. UK and Lithgow and Others $v$. $U K^{238}$ are cited to show that Article $\mathrm{I}_{4}$ has increasing autonomy in the sense that the facts of the case must fall under the ambit of one of the substantive articles in the Convention, while it is not necessary for the substantive article to be violated. ${ }^{239}$ Finally, Hugh fordan v. $U K^{240}$ is used to illustrate statistical discrimination under Article I4, when the ECtHR reasoned that despite the fact that statistically more Catholics or members of a nationalist community were killed by the security forces in the conflict in Northern Ireland, these statistics were not considered to provide evidence for discriminatory practice by the secret service. ${ }^{24 \mathrm{I}}$

The German textbook's 66 discord cases, of which 4 have a particularly high in-degree ranking, illustrate 4 aspects of Article I4: the non-exhaustive list of discrimination grounds in Article I4, the special role of gender discrimination, discrimination on the grounds of ethnic origin and justification of discrimination on the grounds of birth or social origin requiring very weighty reasons.

Pine Valley Developments Ltd v. Ireland ${ }^{242}$ is used in the German textbook to illustrate that the list of discrimination grounds in Article I 4 is not exhaustive but that distinctions such as in Pine Valley on the nature of a temporary building permit, are acknowledged by the ECtHR. Willis v. UK, concerning

\footnotetext{
${ }^{236}$ Airey v. Ireland App no 6289/73 (ECtHR, 9 October 1979).

${ }^{237}$ National Union and Belgium Police v. Belgium App no 4464/70 (ECtHR, 27 October 1975).

${ }^{238}$ Lithgow and Other v. UK App no 9006/80 (ECtHR, 8 July 1986).

${ }^{239}$ Renucci (n 4) I3O-I3I.

${ }^{240}$ Hugh fordan v. UK App no 24746/94 (ECtHR, 4 August 200I).

${ }^{24 \mathrm{I}}$ Hugh Fordan (n59) I28.

${ }^{242}$ Pine Valley Developments Ltd v. Ireland App no I2742/87 (ECtHR, 29 November I99I).
} 
discrimination against a man in regard to social security benefits in the form of a widower's pension, is used twice to illustrate the central role of gender as a prohibited ground in Article I4. ${ }^{243}$ Velikova v. Bulgaria is used to show that Article $\mathrm{I}_{4}$ is an accessory right in the Convention, as the ECtHR found that the alleged discrimination on the ground of (Roma) ethnic origin needed to be proved beyond reasonable doubt to conclude that the treatment was also discriminatory. Finally, Sabin v. Germany ${ }^{244}$ is used to explain the ECtHR's practice concerning discrimination on the grounds of birth or social origin and in particular the practice of requiring very weighty reasons for differential treatment between legitimate and illegitimate children, i.e. those born to unmarried parents.

Three discord-cases with high in-degree are used in the UK textbook to illustrate three aspects of Article I4: Article I4's non-exhaustive list of prohibited grounds, the burden of proof for discrimination under Article I4 and a procedural aspect of Article 14 as an independent claim. The case of Kjeldsen, Busk Madsen and Pedersen v. Denmark ${ }^{245}$ is used in the UK textbook in relation to Article I4's non-exhaustive list of prohibited grounds and in particular as an example of a line of case law that indicates that the criterion for 'other status' is that of a personal characteristic. Here, the textbooks seem to agree on emphasising the lack of Article I4's independent existence, but the discord cases show that they consider different cases to be illustrative for this aspect of Article I4.

The Chassagnou ${ }^{246}$ case is used to illustrate the practice of the ECtHR regarding the burden of proof in Article I4 cases, where the applicant must show a difference in treatment and the respondent state must demonstrate that such treatment serves a legitimate aim. Finally, Cyprus v. Turkey ${ }^{247}$ sheds light on a line of reasoning adopted by the ECtHR with regard to whether an Article I4 claim forms a complaint separately from the complaint under the

\footnotetext{
${ }^{243}$ Among several other references many of which are shared by the other textbooks.

${ }^{244}$ Sabin v. Germany App no 30943/96 (ECtHR, 8 July 2003).

${ }^{245}$ Kjeldsen, Busk Madsen and Pedersen v. Denmark App no 5095/7I (ECtHR, 7 December 1976).

${ }^{246}$ Chassagnou and Others v. France App no 25088/94 (ECtHR, 29 April 1999).

${ }^{247}$ Cyprus v. Turkey App no 2578I/94 (ECtHR, I2 May 2OI4).
} 
substantive article and therefore whether the ECtHR must examine the case under Article I4.

The discord cases seem to be an indication of the textbook authors' different outlooks and different choices from among the known cases, i.e. those known to the authors. While our focus has only to a limited degree been aimed at those discord cases with a high in-degree, because we consider that these cases represent true value as representative statements of the law, since they are both frequently cited by the ECtHR itself and by one or more of the textbooks, the discord cases with a low in-degree represent the real disparity: the low in-degree cases display discord both among the textbooks and with the ECtHR. As the low in-degree cases take up the vast majority of all the discord-cases, it can be inferred that in each textbook there are a number of cases, about twenty in the French and the UK textbooks and about 60 in the German textbook, which are not referred to either by other legal experts or by the ECtHR itself when accounting for which cases illustrate the law under Article I4. We consider this to be evidence that the textbooks do to some extent rely on the author's subjective outlook, but do so without explicating the basis for this outlook despite the fact there exist measures (network analysis and comparison with other textbooks) that could provide a platform for qualifying that outlook. We can furthermore conclude from our comparison that textbook authors do not, through their more qualitative approach, reach significant agreement about which cases are the most representative and/or illustrative of the law under Article I4 of the ECHR.

\section{Interim Conclusions of Comparison of Textbook Analyses and Network}

From the analysis of the distribution of cases, consensus cases and discord cases, what can we infer about the extent of overlap or disparity among the textbooks, compared to a network approach? The distribution of the textbooks' cases across cases outside the network, consensus, discord cases and overlaps between the individual textbooks shows that the textbooks have less than $50 \%$ of their total reference cases in common, despite the fact that the textbooks (chapters) presumably have a shared purpose, namely to describe the law and practice under Article I4 ECHR. However, the number of consensus cases $(4 \mathrm{I})$ is more than the number of discord cases in the French 
and UK textbooks ( 24 and 25 respectively), yet it is substantially less than the number of discord cases in the German textbook (66).

The 4I consensus cases indicate that a predominant logic of legal expert knowledge in textbook accounts of Article 14 is the chronological order of cases illustrating the development of the ECtHR's practice through emblematic cases from the start of the ECtHR's activity to the present. The study of the consensus cases revealed agreement among the textbooks on $4 \mathrm{I}$ cases and, furthermore, that several of these were also highly cited and can therefore be considered highly relevant in the eyes of the ECtHR too. Nonetheless, consensus cases account only for $12 \%$ of all the references from the three textbooks (342) and $6 \%$ of all cases in the network (636).

\section{CONCLUSIONS: THE BENEFIT OF USING NETWORK ANALYSIS IN LEGAL RESEARCH}

In this article, we have tried to link quantitative data with mainly hermeneutically-oriented research methods by combining network analysis of the ECtHR's citations of its own judgments with qualitative examinations of selected judgments in the network. Our main aim in doing so has been to generally highlight how an empirical basis of legal research that involves case law practice can add a new dimension to the traditional textbook approach used in legal education and scholarship.

To test both the quality of our own results and to assess whether there are special advantages in using this new approach compared with established legal doctrinal research, we have made a comparison with and across three generally recognised textbooks in our chosen area of human rights law. We believe these comparisons have shown that a systematic use of network analysis in structuring legal research in areas where case law is an important source could improve the overall quality of doctrinal analysis. It can do so by more clearly showing which cases are explicitly used in the legal reasoning of the ECtHR and when they are so used. More generally, a change of the methodological approach to the analysis of law so as to include a greater quantity of empirical information, for example about case citations as the basis for a more qualitative analysis, could strengthen the scientific quality of these accounts and hence their value in teaching and in practice. 
Our results also show a clear divergence on a number of points between the different textbooks we have compared; we have found no good reasons for this divergence. We think that it will therefore strengthen the overall objectivity and quality of study in the field if there were some common point of reference for arguing about the importance and relevance of specific cases. Although network analysis does not in and of itself provide a legally rich analysis, it does give a measure of real-world use, which at least yields some standard of objectivity against which one can argue in a particular direction. At least in areas of the law where case citation is frequently used and where case law is generally seen as important, such as in European human rights law and EU law, we find it could generally improve the quality of debate between researchers on which cases are important and hence strengthen awareness of what is 'found' to be the law. Network analysis can help in advancing transparency in legal argumentation by making more explicit whether a specific legal argument deriving from a specific case is also employed consistently in legal practice. As regards scientific gains, using network analysis as a supplementary research tool can enhance the empirical embeddedness of legal research and thereby also advance more informed critical discussions about this practice. 